\title{
(Auto)biografia pioniera. Dziennik i listy Adolfa Januszkiewicza
}

Karina Gaibulina

TEKSTY DRUGIE 2018, NR 6, S. 341-360

DOI: $10.18318 /$ td.2018.6.23

Stawiłem pomnik ponad spiże trwalszy, wyższy nad ogrom królewskich piramid'

Horacy

Na wstępie należałoby zacząć od dekonstrukcyjnego stwierdzenia, że analizowany tekst, po raz pierwszy opublikowany w roku 1861, w swojej istocie nie był ani biografią, ani autobiografią, nie był też napisany przez pioniera, mimo kreowania się autora na takiego. Dlaczego w takim razie książkę Żywot Adolfa Januszkiewicza i jego listy ze stepów kirgiskich odbierano właśnie w ten sposób albo, inaczej: jakie narzędzia zostały wykorzystane w celu przekształcenia prywatnego dziennika prowadzonego przez Adolfa Januszkiewicza w czasie wyjazdu do stepu środkowoazjatyckiego, do książki opisującej wyprawę do terra incognita. Chcąc zrozumieć przebieg tej transformacji,

1 Horacy (Quintus Horatius Flaccus) Dzieła wszystkie: Pieśni (Ody). Jamby (Epody). Pieśń wieku. Gawędy (Satyry). Listy. Sztuka poetycka, przeł. i oprac. A. Lam, ASPRA-JR, Pułtusk-Warszawa 2010, s. 97.

\section{Karina Gaibulina}

- mgr, doktorantka na Uniwersytecie St. Gallen w Szwajcarii, prowadziła zajęcia w Instytucie Kultury Polskiej UW „Spotkanie kultur: postkolonializm i jego konteksty". Zajmuje się studiami postkolonialnymi, teorią oralności i piśmienności, praktykami piśmiennymi oraz dokumentami osobistymi polskich zesłańców na Syberii. Autorka książki Adolf Januszkiewicz. 24 lata zesłania na Syberii: pomiędzy "cywilizacja"

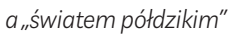
(2014). Kontakt: k_gaibulina122@ mail.ru. 
powinniśmy przyjrzeć się zarówno praktyce diarystycznej Januszkiewicza, jak i częściom składowym jego dokumentów osobistych oraz pracy redaktorskiej, która zaważyła na ostatecznym kształcie publikacji.

\section{Rys biograficzny}

Adolf Walerian Julian Januszkiewicz urodził się 28 maja/9 czerwca 1803 roku w Nieświeżu. Otrzymawszy podstawowe wykształcenie najpierw w rodzinnej miejscowości, a następnie w gimnazjum w Winnicy ${ }^{2}$, w 1821 roku przybył do Wilna, aby kontynuować studia wyższe na Uniwersytecie Wileńskim, gdzie "bawił 2 lata”, słuchając wykładów na wydziale literackim4. Tu poznał m.in. Adama Mickiewicza i dołączył do kręgu filaretów i filomatów ${ }^{5}$, grona młodych ludzi wysoko ceniących równość społeczną, wartości demokratyczne oraz wierzących w utopijne ideały oświeceniowe wiecznego postępu, przemian cywilizacyjnych, a także powszechną edukację i siłę rozumu6. Po powrocie na Podole w 1826 roku Januszkiewicz został wybrany do Sądu Głównego Izby Cywilnej w Kamieńcu, gdzie pełnił funkcję deputata w ciągu następnych trzech lat.

W grudniu 1830 roku, po wybuchu powstania listopadowego, udał się do Wilna, a stamtąd do Warszawy, by dołączyć do szeregów powstańców. Jednak wkrótce z ciężkimi ranami nogi i głowy został zatrzymany przez oddział Kozaków. Sąd w Kijowie skazał Januszkiewicza na karę śmierci, którą zastąpiono zesłaniem na osiedlenie do Syberii z pozbawieniem wszelkich tytułów, szlachectwa i majątku? W maju 1832 roku przybył do Tobolska, a w 1834 roku przeniósł się do Iszymu, gdzie mieszkał prawie 8 lat. Z kolei w czerwcu 1841 roku na mocy manifestu cesarza Mikołaja I ogłoszonego z okazji ślubu następcy tronu Aleksandra II kilku zesłańcom łącznie z Januszkiewiczem

\footnotetext{
2 J. Odrowąż-Pieniążek Przedmowa, w: A. Januszkiewicz Listy z Syberii, oprac. H. Geber, Czytelnik, Warszawa 2003, s. 6-7.

3 BPP475, s. 651.

4 Nie wiemy jednak, czy te studia ukończył, ponieważ nie ma jednoznacznych na to dowodów. M. Król, K. Gaibulina Adolf Januszkiewicz. 24 lata zesłania na Syberii. Pomiędzy "cywilizacja" a „światem półdzikim”, "Wrocławskie Studia Wschodnie” 2015 nr 19, s. 288.

5 Ф.И. Стеклова Тайна одного письма, „Советское Славяноведение” 1977 nr 1, s. 101-103.

6 A. Witkowska Rówieśnicy Mickiewicza. Życiorys jednego pokolenia, Rytm, Warszawa 1998, s. 52-55.

7 J. Odrowąż-Pieniążek Przedmowa, s. 21-22.
} 
zezwolono podjąć pracę w rosyjskiej służbie cywilnej lub wojskowej na terenie Syberiii. Pragnieniem Januszkiewicza było, aby sumienną pracą pod okiem naczelnika gubernialnego uzyskać amnestię i pozwolenie na powrót do domu. W związku z tym przeniósł się do Omska, gdzie został zatrudniony najpierw w Sądzie Okręgowym, a następnie w kancelarii Pogranicznego Naczelnika Syberyjskich Kirgizów. Nowe stanowisko stawiało przed Januszkiewiczem nowe wyzwania, musiał bowiem zapoznać się z językiem kazachskim, prawami i zwyczajami Kazachów, jak również pogłębić swoją znajomość języka rosyjskiegoª . Jego praca polegała na przygotowywaniu sprawozdań i czytaniu raportów sporządzanych przez „sułtanów, naczelników okręgów, prezesów dywanów"10. Ponadto uczestniczył w projektach układania postanowień regulujących zarządzanie Stepowym Krajem"1, o czym pisał do swojego przyjaciela Gustawa Zielińskiego:

Ja prawodawca Kirgizów! Czy mi to się śniło kiedy! O, dziwne losy człowieka - potomkowie Dzyngis-chana za lat 16 tysięcy na kartkach swojej przeszłości czytać będą moje imię i powiedzą, że to był drugi Konfucjusz-Zoroaster, a kto wie, może na część moją wystawią jakiego bałwana i na moim grobie składać będą takie ofiary. ${ }^{12}$

Ponadto, zatrudniony w rosyjskiej administracji, Januszkiewicz uzyskał możliwość zapoznania się z dokumentami archiwalnymi dotyczącymi relacji między Imperium Rosyjskim a mieszkańcami Azji Środkowej oraz okazję odbycia trzech podróży do stepów środkowoazjatyckich, dzięki czemu nieco bliżej poznawał życie koczowników. Trzecia, najdłuższa wyprawa trwała od maja do początku października 1846 roku, podczas której Januszkiewicz, przebywając cały czas wśród Kazachów i wykonując powierzone mu zadania służbowe, prowadził jednocześnie swój słynny dziennik osobisty.

8 A. Januszkiewicz Listy z Syberii, oprac. H. Geber, Czytelnik, Warszawa 2003, s. 177.

9 Tamże, s. 205.

10 Pismo stanowiło nieodłączny element biurokratyczno-administracyjnego sposobu sprawowania władzy w Imperiach Zachodnich, na ten temat pisali zarówno M.L. Pratt Imperialne spojrzenie. Pisarstwo podróżnicze a transkulturacja, przeł. E.E. Nowakowska, Wydawnictwo U), Kraków 2011 S. 54, 62 oraz J. Goody Logika pisma a organizacja społeczeństwa, przeł. G. Godlewski, Wydawnictwa UW, Warszawa 2006, s.114, 170-171, 182.

11 W ten sposób nazywano terytorium należące do Średniej Hordy.

A. Januszkiewicz Listy z Syberii, s. 219. 
Trzy lata później, w 1849 roku, Januszkiewicz porzucił nadzieję „zasłużenia" na ułaskawienie i podał się do dymisji. Niezależnie jednak od tego otrzymał pozwolenie na pozostanie w stolicy Syberii Zachodniej - Omsku. Staraniami jego młodszego brata Eustachego, przebywającego na emigracji w Paryżu przeniesiono Adolfa w 1853 roku do Niżnie-Tagilska ${ }^{13}$. Mimo usiłowań całej rodziny dopiero w roku 1856, po wstąpieniu na tron Aleksandra II, Januszkiewicz został uwolniony od kary i mógł powrócić do kraju ${ }^{14}$. Niestety gdy tylko przybył do domu, okazało się, że był już śmiertelnie chory. Zmarł w Dziahylnie 6/19 czerwca 1857 roku.

Przez cały okres zesłania Adolf Januszkiewicz prowadził obszerną korespondencję z rodziną i przyjaciółmi. Jego najmłodszy brat January regularnie przesyłał mu książki i czasopisma dozwolone przez cenzurę ${ }^{15}$. Adolf z wielkim zainteresowaniem czytał prace historyczne, etnograficzne i podróżnicze, w tym także wcześniejsze publikacje opisujące azjatycką część Imperium Rosyjskiego, takie jak książka Otrywki o Sybiri, autorstwa Matwieja Hedenströma, którego Adolf osobiście poznał w Tobolsku w 1832 roku $^{16}$, albo tekst Józefa Kobyłeckiego Wiadomości o Syberyi i podróże w niej odbyte ${ }^{17}$, który zdaniem Januszkiewicza, mimo że był napisany „bez żadnego systematu”, a wiele przedmiotów w nim potraktowanych zostało „bardzo powierzchownie [...], w ogóle zasługuje na wiarę"18. Z kolei prawdziwym odkryciem stała się dla niego lektura listów z wyprawy do Indii i Tybetu francuskiego przyrodnika i podróżnika Victora Jacquemonta ${ }^{19}$, o czym wspominał do brata:

Niestety przewrócił mnie mnóstwo wyobrażeń,jakie miałem o Indii. [...] ledwo nie wszystko w innej maluje postaci, pod jaką ja marzyłem o tym

13 Tamże, s. 321.

F. Stiekłowa W kręgu Zielińskiego i Januszkiewicza, w: Społeczeństwo polskie i próby wznowienia walkizbrojnejw1833 roku/Польское общество и попытки возобновления вооруженной борьбы в 1833 году, Ossolineum, Wrocław 1984, s. 186.

A. Januszkiewicz Listy z Syberii, s. 53.

Tamże, s. 124.

J. Kobyłecki Wiadomości o Syberyi i podróże w niej odbyte w latach 1831, 1832, 1833, 1834, Warszawa 1837.

A. Januszkiewicz Listy z Syberii, s. 164 .

V. Jacquemont Letters from India, 1829-1832; being a selection from the correspondence of Victor Jacquemont, transl. C.A. Phillips, J. Sidney L. \& K.G. Lethbridge, London-Macmillan 1936. 
kraju. Ach! tak to nie raz było ze mną, kiedym jechał po Europie. Rzeczywistość pokazywała co innego niż to, com nieraz w książkach wyczytał. ${ }^{20}$

January w swoich listach także okazywał żywe zainteresowanie miejscem pobytu brata i nalegał, by Adolf przesyłał mu relacje z „barwą miejscową”, na co Adolf odpowiadał: „jak poznam tę część nie omieszkam udzielić Ci obszerniejszych wiadomości"21. Czytane książki oraz korespondencja z bratem niewątpliwie zainspirowały Adolfa do podjęcia wyzwania opisania „stepu kirgiskiego"22 nieznanego jeszcze w tym czasie w Europie. Dziełem tym miał stać się właśnie dziennik osobisty z trzeciej podróży. Pamiętając o tym marzeniu Adolfa, już po jego śmierci w 1859 roku Gustaw Zieliński przekazał rękopis i całą korespondencję prowadzoną z rodziną i przyjaciółmi w czasie zesłania do Eustachego w Paryżu, zamierzającego na podstawie zebranych dokumentów przygotować obszerną publikację, by upamiętnić dokonania brata. Pierwsze wydanie korespondencji Januszkiewicza wraz z dziennikiem z podróży, zatytułowane Żywot Adolfa Januszkiewicza ijego listy ze stepów kirgiskich i sfinansowane przez jego rodzinę, ukazało się w roku $1861^{23}$.

\section{Dziennik z wyprawy}

Wszystkie dzienniki w swojej istocie były praktyką solipsystycznych, chaotycznych i selektywnych wpisów oznaczonych datą i pełniły funkcję filtru porządkującego otaczającą diarystę rzeczywistośśc ${ }^{24}$. Wobec tego w celu ponownego odczytania „znaczenia dzienników” osobistych w ich integralnej

20 A. Januszkiewicz Listy z Syberii, s. 136.

21

Tamże, s. 190.

WXIX wieku Kazachowie byli nazywani przez władze imperialne Kirgizami, natomiast Kirgizów określano Karakirgizami.

Żywot Adolfa Januszkiewicza i jego listy ze stepów kirgiskich, Księgarnia B. Behr'a, Berlin-Poznań 1861 , t. 1, 2. Wyborem i opracowaniem materiału zajął się Felix Wrotnowski, który dokonał znacznych przekształceń stając się do pewnego stopnia jego współautorem; A. Januszkiewicz Listy ze stepów kirgiskich i dziennik podróży, oprac. H. Geber, PTL, Wrocław 2013. Wydanie to $w$ istocie stanowi ponowną publikację pracy Wrotnowskiego. Wszystkie te wydania zawierały znaczne modyfikacje i przekształcenia, a w związku z tym konieczne było także skorzystanie z rękopisu dziennika i części listów z wyprawy, przechowywanych w Polskiej Bibliotece w Paryżu.

4 Ph. Lejeune „Drogi zeszycie...", „drogi ekranie...". O dziennikach osobistych, przeł. A. Karpowicz, M. i P. Rodakowie, Wydawnictwa UW, Warszawa 2010, s. 51-56. 
całości Paweł Rodak zaproponował analizę praktyki prowadzenia codziennych notatek ${ }^{25}$, zwracając szczególną uwagę na jej pragmatyczny i utylitarny aspekt. Takie spojrzenie na dziennik jest niezbędne, by ponownie przemyśleć jego zawartość merytoryczną. Jednak czy istnieje możliwość dotarcia do czegoś, czego nie jesteśmy w stanie zobaczyć, czegoś, co raz na zawsze się skończyło wraz z zaniechaniem samej praktyki? Czy jest możliwe, by posłużyć się zwrotem Clifforda Geertza, wyjście poza "sieć znaczeń” stworzonych przez samego człowieka ${ }^{26}$ ? Albo inaczej: czy możemy dostrzec świat pozajęzykowy w jego semiotycznej, utrwalonej na papierze postaci? W przypadku dokumentów osobistych mamy do czynienia jedynie ze śladami pozostałymi w samej materialności rękopisu oraz w autorefleksyjnych komentarzach pamiętnikarza.

Dziennik z wyprawy Januszkiewicza można zaliczyć do dzienników podróży mających jasno określone ramy czasowe zbieżne z jej rozpoczęciem i zakończeniem. Rękopis diariusza składał się z dwóch części: pierwszą stanowiły kartki złożone na pół i później zszyte do jednego zeszytu, natomiast druga jego część była pisana na luźnych, dwa razy mniejszych stronicach, także złożonych na pół. Z listu Gustawa Zielińskiego do Eustachego Januszkiewicza wiadomo, że początek dziennika, obejmujący okres od 8 maja do 13 czerwca, został własnoręcznie zniszczony przez samego Adolfa, a niektóre fragmenty przekreślone ${ }^{27}$. Januszkiewicz prowadził notatki prawie codziennie, czasami uzupełniając niektóre wpisy w dniu następnym, np. streszczał wieczorną rozmowę bądź relacjonował nocną przygodę, jak było w przypadku napadu złodziei na tabun koni należących do aułu, w którym akurat stacjonował jego oddział. Ponadto na każdej stronie pozostawiał spore marginesy na dole oraz po lewej stronie, gdzie sporządzał na bieżąco przypisy bądź dopisywał post factum wyjaśniające komentarze do głównego tekstu. Na początku dziennika wpisy były dość obszerne i różnorodne pod względem tematycznym. Natomiast w drodze powrotnej stawały się coraz krótsze i bardziej monotonne. Wraz z rozpoczęciem pisania drugiej części na mniejszych kartkach notatki stały się jeszcze bardziej lakoniczne.

25 P. Rodak Między zapisem a literaturą. Dziennik polskiego pisarza w XX wieku, Wydawnictwa UW, Warszawa 2011, s. 36-38. 2005, s. 19.

27 Trudno jednoznacznie określić, które fragmenty skreślił sam Januszkiewicz po przelaniu zebranego materiału do listów wysyłanych do rodziny i przyjaciół w czasie wyjazdu, a które zostały odrzucone podczas przygotowywania dziennika do publikacji przez Wrotnowskiego. 
W trakcie wyjazdu Januszkiewicz symultanicznie prowadził dziennik, pisał listy oraz, jako pracownik imperialnej administracji, sporządzał raporty służbowe. Wszystkie wymienione rodzaje praktyk piśmiennych wzajemnie się na siebie nakładały i odzwierciedlały w samym diariuszu. Należy jednak odróżnić „listy kirgiskie”, jak nazywał je Januszkiewicz, od reszty jego korespondencji, stanowiły one bowiem odrębną jakościowo całość, wzorowaną niewątpliwie na książce Jacquemonta. Niektóre z tych listów, jak np. list adresowany do brata Januarego na początku wyprawy ${ }^{28}$, były pisane w ciągu kilku dni, przypominały minidziennik. Były w nich poruszane takie tematy, jak: przebieg podróży, szczegółowe szkice miast, portrety wybitnych osób społeczności kazachskiej, a także ciekawostki z życia koczowników, jak np. opis sądu tradycyjnego czy rywalizacji poetów oralnych w sztuce improwizatorskiej. Z kolei w części dziennika pisanej w drodze powrotnej, podczas której Januszkiewicz miał za zadanie przeprowadzenie spisu ludności i majątku, widać było coraz większy wpływ praktyki spisywania raportów, przejawiający się m.in. w postaci zapisów statystyk - ludności, bydła, topografii koczówek poszczególnych rodów, odległości między postojami itp. ${ }^{29}$.W odróżnieniu jednak od podobnych dzienników prowadzonych przez rosyjskich urzędników, które później służyły jako podstawa składanych raportów, prywatne notatki Januszkiewicza odzwierciedlały przebieg pełnionych w trakcie wyprawy zadań służbowych.

Praca w administracji a także wykonywane przez Januszkiewicza obowiązki, zarówno podczas wyjazdów do stepu, jak i w biurze w Omsku, wskazywały na kolejną kwestię niezbędną do analizowania zarówno samej praktyki prowadzenia dziennika, jak i procesu kognitywno-interpretacyjnego Januszkiewicza, mianowicie nakładanie się na siebie niezależnych źródeł wiedzy o stepie. Umownie można je podzielić na trzy kategorie: „archiwa”, zarówno związane z funkcjonowaniem administracji imperialnej, jak i publikacje dotyczące wschodniej części Imperium Rosyjskiego; „rozmowy” z ludźmi spotkanymi w trakcie wyjazdu; oraz osobiste „obserwacje" poczynione w tym czasie. W związku z tym struktura jego dziennika przypominała kolaż lub patchwork, gdzie niezależne części złożone w całość tworzą nowe znaczenie.

Archiwum, jako nieodłączna instytucja nowożytnych imperiów europejskich, stanowiło podstawowy element kultury piśmiennej, a w szczególności

\footnotetext{
28 A. Januszkiewicz Listy ze stepów kirgiskich, s. 43-51. Ten list był pisany w ciągu trzech dni, od 23 do 25 maja. 
kultury typograficznej, pozwalający na kwantyfikację i dystrybucję wiedzy na niebywałą do tej pory skalę ${ }^{30}$.Zatem Januszkiewicz, sporządzając wszelkiego rodzaju spisy czy sprawozdania, nie tylko przyczyniał się do powiększania zasobów archiwów rosyjskich, lecz także świadomie wykorzystywał w swoim dzienniku dane zaczerpnięte z czytanych przez niego w biurze raportów. $\mathrm{W}$ ten sposób powstały merytoryczne opisy miast syberyjskich, wraz z informacjami o ich położeniu, klimacie, roli w systemie ekonomicznym i politycznym Imperium, a także fragmenty poświęcone kontekstom historycznym i warunkom przyjęcia w poddaństwo ostatniej niepodległej części Kazachów ${ }^{31}$. Jeśli chce się natomiast ujawnić intertekstualne zależności notatek Januszkiewicza od szerszego pojęcia „archiwum”, obejmującego również zachodni dyskurs wiedzy o świecie, należy posłużyć się Bachtinowską kategorią „dialogowości”, rozumianą jako dynamiczna relacja i współzależność każdego, nawet najbardziej subiektywnego twierdzenia, od szeroko rozumianej sieci wypowiedzi ${ }^{32}$. Konstruując bowiem swoją opowieść o środkowoazjatyckiej terra incognita, Januszkiewicz czynił zarówno bezpośrednie odwołania do innych tekstów - poprzez polemikę czy cytowanie autorytetów naukowych, jak i pośrednie - poprzez wykorzystywanie XIX-wiecznych kategorii orientalistycznych, czynienie aluzji bądź poprzez strukturalne zapożyczenia. Jako przykład bezpośredniej relacji dialogowej może posłużyć cytat z listu do Michała Moraczewskiego i Pawła Cieplińskiego:

Jeśliście czytali Jacquemonta i pamiętacie opis pochodu wielkorządcy Indii z Kalkuty na brzeg Sutledży, nasza wyprawa teraźniejsza wielce go przypomina. Cała tylko różnica, że tam były słonie i palankiny, a u nas wielbłądy i jurty. ${ }^{33}$

Dzięki przywołaniu znanego przyjaciołom opisu ze wspólnej lektury Januszkiewicz lakonicznie scharakteryzował przebieg wyprawy, w której uczestniczył, oraz wpisał ją do ogólniejszej narracji eksploratorsko-podróżniczej, do jakiej uprzednio zaliczono książkę Jacquemonta. Natomiast

30 W.J. Ong Oralność i piśmienność. Słowo poddane technologii, przeł. J. Japola, RWKUL, Warszawa 2011, s. 197.

A. Januszkiewicz Listy ze stepów kirgiskich, s. 21, 26-27, 56-58, 63-65.

M. Bachtin Estetyka twórczości słownej, przeł. D. Ulicka, PIW, Warszawa 1986, s. 359-361. 
w liście do brata, kreśląc obraz stolicy Zachodniej Syberii Omska, odwoływał się do autorytetu Alexandra von Humboldta, przekonując, że te „okolice zalewały niegdyś, jak świadczy Humboldt, fale oceanu"34. W innym miejscu, chcąc zarysować prawo zwyczajowe Kazachów, o którym miał jedynie powierzchowne pojęcie, sparafrazował rosyjskiego niekwestionowanego w tym okresie znawcę życia stepowego, pisząc, że „u Kirgizów, jak to i Lewszyn pisze, władza rodziców nad dziećmi jest nieograniczona do pełnole-

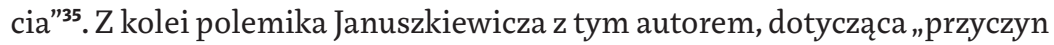
zimna w stepie", ostatecznie została skreślona przez Wrotnowskiego podczas procesu redakcyjnego ${ }^{36}$.

Trudniejszą kwestią do prześledzenia są natomiast pośrednie relacje intertekstualne dziennika Januszkiewicza z czytanymi wcześniej tekstami. Jak zostało zaznaczone wcześniej, Januszkiewicz, należąc do pokolenia filaretów wierzących w siłę rozumu i nieustanny postęp, wyniósł z tego środowiska m.in. wartościujący dyskurs oświeceniowo-ewolucjonistyczny, który był także podstawowym modelem interpretacyjnym dla ówczesnych nauk humanistycznych. Popularne binarne kategorie naukowe pozwalały „odkrywać” nowy świat poprzez narzucanie znanych schematów epistemologicznych. Ilustracją absorpcji i stosowania tego ujednolicającego rodzaju słownictwa przez Januszkiewicza mogą być jego aluzje podczas wędrówki po stepie środkowoazjatyckim do obrazu Palestyny ${ }^{37}$ czy Arabii i Beduinów ${ }^{38}$ bądź porównanie pracujących przy żniwach Kazachów do „Negrów na plantacjach”39, a wegetację wzdłuż rzeki Ajaguzy do brazylijskiego lasu ${ }^{40}$. O wiele ciekawsze były jednak zapożyczenia gotowych struktur językowych. Na przykład w liście do brata Januarego Adolf, chcąc sportretować miasto Semipałatyńsk, pisał, że „język kirgiski w powszechnym prawie używaniu. Płeć nawet piękna rosyjskiego plemienia mówi nim biegle, jak nasze damy po francusku"41. Obraz

A. Januszkiewicz Listy ze stepów kirgiskich, s. 26.

Tamże, 180-181.

BPP476, s. 445 .

A. Januszkiewicz Listy ze stepów kirgiskich, s. 179.

Tamże, s. 193.

Tamże, s. 130.

Tamże, s. 57.

Tamże, s. 26.
} 
ów okazał się być kalką z książki Hedenströma, w której autor podobnie przedstawiał Jakuck, mianowicie: „głównym językiem używanym w mieście jest Jakucki. Nawet szanowane Panie nie wstydzą się mówić nim na spotkaniach, jak w Rosji po francusku" ${ }^{\prime 2}$. Z kolei w innym miejscu, gdy opis tekstowy nie odpowiadał zastanej rzeczywistości, Januszkiewicz wchodził w ukrytą polemikę. Tak uczynił to w odniesieniu do dokonanego przez Lewszyna porównania koczowników do mieszkańców Arkadii, którzy w jego przekonaniu, mimo braku rozwiniętej medycyny odznaczali się dobrym zdrowiem ${ }^{43}$.Tymczasem Januszkiewicz nie bez rozczarowania i współczucia zanotował: „nie wszystko złoto, co się święci z góry! W każdej jurcie spodziewałem się znaleźć szczęśliwych pasterzy Arkadii... niestety! Rzadko w której nie spotkał mój wzrok smutnych obrazów nędzy i chorób" ${ }^{44}$. Dzięki strategiom zapożyczania i negacji Januszkiewicz nie tylko dokonywał „orientalizacji” stepu i koczowników poprzez stosowanie skonwencjonalizowanego modelu lingwistycznego, lecz także pozycjonował samego siebie jako zewnętrznego obserwatora. Taki tryb konstruowania opowieści był nazywany przez Mary Luis Pratt narracją „antypodbojową", gdzie dyskursy naukowe, mesjanistyczne czy humanitarne stanowiły gwarancję „bezinteresowności” i odgrywały zasadniczą rolę w kreowaniu europejskiego wyobrażenia reszty świata oraz pozwalały z nim się oswajać ${ }^{45}$.

Kolejną istotną kwestią, na którą trzeba zwrócić uwagę przy analizie dziennika Januszkiewicza, jest problem połączenia wiedzy zaczerpniętej z prac naukowych z jego własnymi orientalistycznymi wyobrażeniami na temat „dzikich”ludów wschodu. Za przykład takiego połączenia może posłużyć wpis zrobiony w drodze powrotnej, gdy Januszkiewicz miał coraz mniej możliwości, aby osobiście uczestniczyć w wydarzeniach z życia nomadów i bezpośrednio obserwować ich tradycję i kulturę:

O swatach u Kirgizów. Gdy ci mają przybyć, przy progu jurty kopie się dół zakryty trawą. Jak tylko swaty przez próg przestąpią, dziewki i wszystka młodzież w jurcie ciskają na nich kwieciem, jak kamieniami.

М. Геденштром Отрывки о Сибири, Санкт Петербург 1850, s.85 [przeł. K. Gaibulina] А.И. Левшин Описание киргиз-казачьих или киргиз-кайсацких орд и степей, t. 3, Санкт Петербург 1832, s.18, 36. 
Ci tymczasem wpadają w dół: śmiech, hałas. Wyrządzają im różne figle: dziewczęta ich rozzuwają, targając i łaskocząc; sadzają na krowę lub byka, czasem nawet z nagą dziewką, i związawszy razem puszczają w step, ale pilnują wszakże, żeby nie było przypadku. [...] Przez ten czas panna młoda, często sześć lub siedem lat mająca, siedzi w drugiej jurcie.

Pogrzeb kirgiski krótki. Jak tylko Kirgiz umrze, baby w jurcie straszny krzyk podnoszą. Starają się potem jak najprędzej go umyć, zawijając w sawan biały bawełniany [...], i niosą do dołu wykopanego niegłęboko. Tu kładą trupa z rękami wyciągniętymi obok ciała, a przykrywszy trawą lub gałązkami drzew, zasypują ziemią. ${ }^{46}$

Patrząc na drugą relację, należy zaznaczyć, że Januszkiewiczowski opis pogrzebu był bardzo schematyczny i powierzchowny, a klucz do jego rozumienia znajdował się w zdaniu „baby w jurcie straszny krzyk podnoszą”. W odróżnieniu od zredagowanej przez Wrotnowskiego wersji, w rękopisie ów komentarz został dopisany do głównej narracji pod koniec akapitu, jako dodatek, który być może Januszkiewicz przypomniał sobie dopiero w trakcie pisania, albowiem wątek ten pojawiał się zarówno w tekście Lewszyna, jak i u Kobyłeckiego ${ }^{47}$.

Natomiast o wiele bardziej zastanawiający jest szkic „swatów” kazachskich. Przede wszystkim koczownicy uważali za najbardziej odpowiedni wiek zamążpójścia dla kobiety około lat 16 (z kolei dla mężczyzny 15) ${ }^{48}$, a więc obraz? sześcio- czy siedmioletniej niewiasty został wyłuskany z opowieści o muzułmańskim Bliskim Wschodzie i przeniesiony przez Januszkiewicza na Kazachów. Za uzasadnienie takiego zabiegu posłużyła zasada podobieństwa w postaci wspólnoty wiary między mieszkańcami tych dwóch obszarów. Z kolei wspomniany przez autora akt obnażania w kazachskim prawie zwyczajowym miał zdecydowanie inne znaczenie, stanowił jeden ze środków penitencjarnych za cudzołóstwo, bluźnierstwo albo za oczernianie rodziców, zgodnie z którym osobę oskarżoną o wykroczenie rozbierano do pasa, wsadzano na krowę i przywiązywano z posmarowaną popiołem twarzą do ogona i w ten sposób wożono po aułu, zmuszając do wyjaśniania

46 A. Januszkiewicz Listy ze stepów kirgiskich, s. 127-128; BPP476, s. 31. 
publiczności własnego występ $\mathrm{ku}^{49}$. Januszkiewicz w swojej narracji połączył ów barwny obraz wykonywania wyroku, zaczerpnięty zapewne z książki Lewszyna, z zasłyszaną od osoby trzeciej opowieścią o kazachskim weselu oraz wcześniejszymi wyobrażeniami o muzułmańskim wschodzie, konstruując w ten sposób wizję obrzędu ślubnego niemającą nic wspólnego z rzeczywistością.

Ponadto pod koniec wyprawy Januszkiewicz narzekał, że „żadna nowa materia nie przybywa do dziennika: wszystko jedno a jedno" ${ }^{\text {", }}$, w związku z tym coraz więcej miejsca poświęcał opisom swych obowiązków oraz streszczał tematy rozmów prowadzonych w czasie przejazdów bądź wieczorem przy ognisku. Rozmowy te pełniły dla niego funkcję lustra, w którym przyglądał się życiu stepowemu. Będąc przedstawicielem imperialnej administracji i bardzo pobieżnie znając język kazachski, Januszkiewicz miał znacznie ograniczone możliwości komunikacji. Głównymi jego informatorami byli inni urzędnicy, jak np. polski zesłaniec, przyjaciel i współpracownik w administracji rosyjskiej Wiktor Iwaszkiewicz, scharakteryzowany jako „znający wybornie ich [Kazachów] język"51 a także Kozacy, tłumacze, oraz wąska grupa przedstawicieli kazachskiej elity znających język rosyjski, jak np. sułtan Barak, w którego „natura” zdaniem Januszkiewicza „obok niepospolitych zdolności umysłowych wlała [...] tęgi charakter i nieustraszone męstwo"52, bądź bij ${ }^{53}$ Kunanbaj „obdarzony z natury zdrowym rozsądkiem, zadziwiającą pamięcią i wymową"54. Podobna przychylna charakterystyka oparta na autorytecie jednostek zaznajomionych per se z obyczajami koczowników podnosiła rangę relacji otrzymanych od nich. Ciekawy przykład pod tym względem stanowi cytat z dziennika:

49 Материалы по обычному казахскому праву, собранные чиновником особых поручений Д’Андре в 1846 году, w: Материалы по казахскому обычному праву, s. 130; Т.М. Культелеев Уголовное обычное право казахов (Смомента присоединения Казахстана к России до установления советскои власти), Алма-Ата 1955, s. 243, 287; А.И. Левшин Описание киргиз-казачьих, s. 174. A. Januszkiewicz Listy ze stepów kirgiskich, s. 219. Tamże, s. 47. Tamże, s. 72. W języku kazachskim bij oznacza sędzię, czyli osobę znającą prawo zwyczajowe i rozpatrującą spory sądowe. A. Januszkiewicz Listy ze stepów kirgiskich, s. 73. 
Przyszedł jakiś młody pastuch skarżyć się na swego pana, że mu urżnął kawałek ucha i łeb przeciął [...]. Do uszu, jak widzę, mają oni szczególniejszą skłonność: często one figurują w sprawach, które rozpatrywałem. Wiktor opowiadał, [...] przyprowadzono raz do obozu kilku Kirgizów złapanych z ich przedniej straży. [...] nagle jeden z przewodników dobywa nożyk, rzuca się na jednego z jeńców i urznąwszy mu ucho zaczyna je gryźć zębami. ${ }^{55}$

Przykład ów demonstrował nakładanie się na siebie wszystkich trzech rodzajów wiedzy wykorzystywanych przez Januszkiewicza w trakcie pisania swojego dziennika: archiwów imperialnych, osobistych obserwacji, a także opowieści specjalisty w tym zakresie, jakim dla Januszkiewicza był Iwaszkiewicz (mający skądinąd skłonność do wyolbrzymiania i przejaskrawiania swoich historii, nadmiernie demonizując i prymitywizując koczowników). Za pośrednictwem komparatystycznego podejścia do badanego przedmiotu Januszkiewicz z jednej strony wypełniał braki wiedzy na temat kultury i tradycji mieszkańców stepu, a także weryfikował własne wyobrażenia na ten temat. Ponadto starał się przedstawić holistyczny obraz życia stepowego, opisując go takim, jakim mu się przedstawiał i jakim go poznał. Naśladując styl narracyjny i formę Jacquemonta ${ }^{56}$, dążył w swojej pracy do rozwiewania mitów na temat "dzikich ludów".Z drugiej zaś strony, stosując oświeceniowe kategorie dychotomiczne oraz gotowe struktury poznawcze, a także bezkrytycznie przywołując narracje zasłyszane od osób cieszących się jego zaufaniem, sam powtarzał wcześniejsze schematy epistemologiczne, tworząc tym samym nowe przesądy.

\section{Publikacja}

Przygotowywanie dziennika osobistego do wydania oznaczało przeniesienie go ze sfery „pisma” do sfery „druku”. W tym celu dokonano restrukturyzacji jego pierwotnego kształtu poprzez skracanie, redagowanie, czasami cenzurowanie, a także wprowadzanie do wewnętrznej struktury elementów zewnętrznych, takich jak przypisy, spisy treści, noty edytorskie, wstępy itp. ${ }^{57}$.

Tamże, s. 191-192.

Bowiem francuski przyrodnik postawił sobie za cel spisywanie tego, co osobiście słyszał bądź widział na własne oczy. V. Jacquemont Letters from India, s. XXIII.

57 P. Rodak Dziennik osobisty jako praktyka piśmienna: działanie, materialność, tekst, w: Antropologia pisma. Od teorii do praktyki, red. Ph. Artières, P. Rodak, Wydawnictwa UW, Warszawa 2010, s. 176. 
Pierwszym redaktorem dziennika z wyprawy był sam Januszkiewicz, który jeszcze przebywając w stepie, wspominał o zamiarze opracowania swojego dziennika, czemu dał wyraz w liście do Michała Moraczewskiego: „w zaciszu mojej komnatki będę pisał dzieje naszej podróży" ${ }^{58}$, a nawet później nie porzucił swoich ambicji, pisząc do matki w 1853 roku: „jeśli tylko zdrowie pozwoli, mam ochotę wszystkich moich Bikmurzów, Baraków, Kuczuk-Tobuklińców, Kyldy-Nogajów i Kisyktanbejów przekazać potomności"59.

Zniszczony początek oraz skreślenia ujawniały świadomą ingerencję diarysty w swoje notatki, jak również chęć dopasowania powstającego tekstu do wybranych wzorców pisarskich. Ponadto wskazywały one na dominującą funkcję dziennika Januszkiewicza. Stanowił on dla niego przede wszystkim „narzędzie pracy intelektualnej”, służące do napisania książki o wyprawie do kazachskiego stepu. Natomiast pozostałe funkcje dziennika, takie jak rejestracja przebiegu wyprawy, autorefleksja czy sporządzanie notatek przez urzędnika imperialnego, były zdecydowanie drugorzędne. Co więcej, zniszczenie diariusza stanowiło strategię zatarcia śladów procesu badawczego oraz warunków sporządzania notatek, a także próbę odzyskania kontroli nad „uniezależniającym” się poprzez materializację przekazem. Z kolei listy wysyłane jeszcze w trakcie wyjazdu zawierały wyselekcjonowane i przepracowane fragmenty z dziennika i dlatego stanowiły niezależną całość, zarówno pod względem tematycznym, jak i stylistycznym.

Praktyka przepisywania dziennika do listów stanowiła dopiero pierwszy etap kreacji obrazu Januszkiewicza jako odkrywcy, tworzonego na podstawie napięć kulturowo-cywilizacyjno-językowych. Jako polski zesłaniec na Syberii, był on bowiem zawieszony między Zachodem, reprezentowanym przez Imperium Rosyjskie ${ }^{60}$, a Wschodem w postaci stepu kazachskiego. Miało to bezpośredni wpływ również na wybór tematów zawartych w jego dokumentach osobistych, ukazując dynamikę narracyjną właściwą tekstom orientalistycznym, polegającą na „abjektalnej”"61 strategii konstruowania

58 A. Januszkiewicz Listy ze stepów kirgiskich, s. 197.

59 A. Januszkiewicz Listy z Syberii, s. 337.

60

Poczynając od epoki Piotra Wielkiego, Imperium Rosyjskie przechodziło przez ciąg prozachodnich reform, mających na celu przybliżyć je do Europy Zachodniej pod względem kulturo-cywilizacyjnym, administracyjnym i technologicznym.

61 Zgodnie z teorią Julii Kristevej „abject", tłumaczone jest na polski jako "wy-miot”, jest wyrzuconą na zewnątrz z głębi samego podmiotu jego własną cząstką, uznaną za "nie-ja” i stanowiącą 
tożsamości w stosunku do otaczającej go rzeczywistości przy wykorzystywaniu różnorodnych narzędzi dyskursywnych ${ }^{62}$.W swoich listach kirgiskich Januszkiewicz rozmyślnie wcielał się w rolę pioniera, który otrzymał szansę odkrycia środkowoazjatyckiej terra incognita. Ten wątek został wyraźnie wyeksponowany np. w liście do Gustawa Zielińskiego: „próżno byś szukał na kartach waszych uczonych jeografów mojego Ak-basz-tau, muszę ci powiedzieć, że to miejsce leży w kirgiskim stepie Średniej Hordy, w karkaralińskim okręgu, w pobliżu Gór Dżingistauskich"63. Z kolei swoją misję w ekspedycji Januszkiewicz określał jako bycie „dyplomatą” wśród ludów „znanych [mu] zaledwie z imienia", któremu przypadło pełnić obowiązek „historiografa podróży"64. Ponadto budował napięcie atmosfery niebezpieczeństwa oraz przygody, pisząc o „złodziejach krążących po okolicy"65 bądź, rozprawiając o przebiegu wyprawy, rozważał możliwość starcia wojennego: „pociąnniemy na granicę Wielkiej Hordy dla politycznych z nią układów, a może dalej dla wypłoszenia z jej obrębów sułtana Kenesarego, grającego na mniejszą skalę rolę nowego Jugurty" ${ }^{\prime 6}$. Nieco później przyznał w liście do Michała Moraczewskiego i Pawła Cieplińskiego, że „to życie czynne, pełne poetyckich wrażeń, wcale mi do gustu" ${ }^{\text {. }}$.

Januszkiewicz przedstawiał samego siebie jako oświeconego, cywilizowanego Europejczyka, przeciwstawionego zarówno „dzikości” stepu, jaki „barbarzyństwu" poprzedzających go w stepie urzędników rosyjskich. W ten sposób wyznaczył dla siebie odrębną przestrzeń "pomiędzy”, skąd spoglądał na Obcy świat, będąc zarazem łącznikiem i filtrem przepuszczającym obserwowaną rzeczywistość poprzez sieć struktur myślowych, tworząc jej „fikcyjny” obraz. Bowiem w odróżnieniu od „fałszu” termin „fikcja” zgodnie z jego etymologią fictiō oznacza „wytwór",, ,coś skonstruowanego",,,coś ukształtowanego"68 - nie

zagrożenie dla tożsamości podmiotu ze względu na intymny związek z nim. J. Kristeva Potęga obrzydzenia. Esej o wstręcie, przeł. M. Falski, Wydawnictwo UJ, Kraków, 2007, s. 7-10.

I.C. Schick Seksualność Orientu. Przestrzeń i eros, przeł. A. Gąsior-Niemiec, Oficyna Naukowa, Warszawa 2012, s. 31-32.

63 A. Januszkiewicz Listy ze stepów kirgiskich, s. 167.

64 Tamże, s. 54, 69, 72.

65 Tamże, s. 46.

66 Tamże, s. 58.

67 Tamże, s. 69.

68 C. Geertz Interpretacja kultur, s. 30-31. 
jest antynomią „prawdy”, lecz wskazuje na świadome tworzenie określonej konstrukcji semiotycznej, jaką była dla Januszkiewicza opowieść pioniera.

Pierwsze wydanie dokumentów osobistych Januszkiewicza przypada dopiero na 1857 rok, miesiąc po jego śmieci, w czasopiśmie „Kronika Wiadomości Krajowych i Zagranicznych”, gdzie opublikowano trzy jego listy ${ }^{69}$ anonimowo, co wiązało się najprawdopodobniej z zakazem drukowania dzieł zesłańców ${ }^{70}$. We wstępie wskazywano na walory naukowe listów obfitujących „w szczegóły historyczne, które nam pojaśniają stosunki i położenie owych narodów wśród stepów" oraz stylistyczne, zauważono bowiem, że były „pisane [...] jakby umyślnie do druku"71. Jednak skalę przemiany prywatnej korespondencji w "listy z wyprawy” możemy dostrzec dopiero we fragmentach zamieszczonych w „Bibliotece Warszawskiej”, porównując chociażby list z dnia 24 maja/5 czerwca 1846 roku z jego rękopisem zachowanym w Bibliotece Polskiej w Paryżu. W pierwszej części wydrukowanego materiału zachowano ogólny sens rękopisu, wprowadzając drobne zmiany, jak chociażby zastąpienie słowa "chata" synonimem „chałupa”. Ponadto przeniesiono krótkie fragmenty do nieco późniejszej części tekstu, jak np. opis uroczystości zwanej „bajga”, który opatrzono dodatkowym komentarzem redaktorskim z informacją jakoby odbywała się ona "co rok, podczas bytności pogranicznego naczelnika w stolicy okręgu". Natomiast druga część tego listu, zawierająca rutynowe dla całej korespondencji Januszkiewicza informacje dotyczące jego zdrowia czy omówienia otrzymanych wiadomości z domu - została całkowicie odrzucona ${ }^{72}$. W rezultacie, przez oczyszczanie ze wszystkich tematów prywatnych właściwych dla epistolografii Januszkiewicza, jego listy z wyprawy dopasowano do popularnej wówczas tematyki podróżniczej i eksploratorskiej, co stanowiło drugi etap redakcji dokumentów osobistych.

Stadium zamykającym proces kreowania Januszkiewicza na pioniera było przygotowanie rękopisu dziennika z wyprawy do druku, dokonane przez Feliksa Wrotnowskiego. Podczas gdy „listy kirgiskie”, wydane wcześniej, zostały włączone do nowej publikacji bez żadnych modyfikacji, jako gotowy materiał,

69 Listy z dnia 11 i 12 czerwca do Gustawa Zielińskiego, a także list do matki z 13 lipca.

A. Januszkiewicz Listy z Syberii, s. 293. „nam nie wolno publikować żadnych naszych prac piśmiennych". 
to strukturę rękopisu dziennika zasadniczo zmieniono. Przede wszystkim opatrzono cały materiał wstępem i przypisami (w szczególności dotyczyło to wyrazów z języka kazachskiego i rosyjskiego), ponadto zaznaczono niektóre drobne zmiany wprowadzone podczas opracowywania tekstu, natomiast o innych obszernych skreśleniach i przekształceniach zupełnie nie wspomniano. Jako jaskrawy przykład modyfikacji dokonanych podczas pracy redaktorskiej przywołuję cytat z 15 sierpnia, w którym zostały połączone w jeden dwa pierwotnie niezależne wpisy:

Bakany, służące do podpierania czeharaku, stają się straszną bronią w ręku kobiet w czasie napadu na jurty. Z krzykiem Megier i Furii wypadają z bakanami przeciwko napastnikom i śmielej się bronią niżeli mężczyźni. Często rzucają swe dzieci pod nogi ich koniom lub nadstawiają je pod ciosy dla obudzenia miłosierdzia; niekiedy, zasłoniwszy nimi swe piersi, same zadają razy. Jeśli napastnicy uprowadzają wielbłądy, uczepiają się ich szyi i tak wiszą przez kilka wiorst drogi, wrzeszcząc, klnąc i błagając o zwrot własności. Widział to sam Wiktor w czasie przygotowań do Chiwińksiej wyprawy. Gdy im oddano zabranego wielbłąda całowały go z radości, a na znak ukontentowania chwytały do gęby ziemie i jadły, dziękując ze łzami i z załamanymi nad głową rękami wykrzykując swoje kułduk. Sądny to ma być dzień, kiedy Kirgizy wpadają na jurty, łamią je, tłuką wszelkie naczynia i wszystko w pień wycinają. Skoro jeden złapie rzecz jaką, a drugi jest tego świadkiem, zaraz dopomina się o podział zdobyczy; zawiązuje się stąd spór, który zwykle kończy się na tym, że najpiękniejszy chałat lub dywan rozdziera się po połowie. Jeśli w której jurcie zdarzy się widzieć część rozdartego dywanu, to na pewno lup z baranty. ${ }^{73}$

W celu zwizualizowania schematu połączenia dwóch wpisów zaznaczylam fragment z 24 sierpnia, który przeniesiono do wpisu z 15 sierpnia. Mimo znacznych zmian stylistycznych i lingwistycznych zastąpiono także addytywną narrację, opisującą niszczenie poszczególnych przedmiotów domostwa, „kiedy Kirgizy wpadają na jurty, łamią je, wszystko w pień wycinają, kotły tłuką, wszystkie rzeczy rwą na sztuki"74, właściwą dla opowieści oralnej, redukując ją do syntetycznego ujęcia „tłuką wszelkie naczynia i wszystko w pień 
wycinają", eliminującego nadmierne według zasad literackich powtórzenia. Jednak najważniejsze było wynikające z podobnego zestawienia niezależnych fragmentów przeinaczenie pierwotnego sensu oryginalnych notatek Januszkiewicza. Przywołany w tych notatkach Wiktor, mimo że miał skłonność do przejaskrawiania swoich opowieści, nie widział i nie mógł widzieć na własne oczy momentu podstawiania przez kazachskie matki swoich dzieci pod ciosy napastników. W zapisie z 24 sierpnia mowa wyłącznie o uprowadzaniu wielbłądów. Natomiast poprzez połączenie dwóch opowieści o pokrewnej tematyce mniej prawdopodobny opis podparto autorytetem naocznego świadka, w roli którego wystąpił Wiktor.

W analogiczny sposób połączono ze sobą wiele innych fragmentów dziennika, część wpisów skracano, z kolei niektóre kontrowersyjne opowieści zupełnie wyeliminowano. Jak było np. z zajmującą historią zasłyszaną przez Januszkiewicza od tłumacza towarzyszącego wyprawie, o tym jak podczas służby u jednego naczelnika auła, żony jego przełożonego, wykorzystały nieobecność męża, aby poprosić owego tłumacza, by pokazywał swój członek ${ }^{75}$. Cała ta relacja została sprowadzona do stwierdzenia, że "tłumacze opowiadają niesłychane rzeczy o rozwiązłości ich kobiet"76. Dzięki dokonanym zabiegom redaktorskim chaotyczne wpisy, typowe dla praktyki diarystycznej, usystematyzowano w bardziej lakoniczną, zwartą całość, nadając powstającej opowieści jednolitość i linearność oraz wprowadzając do diariusza „sens globalny”. W ten sposób dziennik Januszkiewicza dosłownie utracił swoją integralność materialną, na rzecz integralności formalnej, charakterystycznej przede wszystkim dla literatury ${ }^{77}$.

Ogłoszenie drukiem opracowanych „listów kirgiskich” i dziennika Adolfa Januszkiewicza miało dalekosiężne konsekwencje bezpośrednio wpływające na przyszłe praktyki ich odczytywania i interpretacji, które nazwałam „technologią obiektywizacji”. Pojęcie „obiektywizacji” należy rozumieć nie jako synonim „neutralności spojrzenia” czy „prawdziwości” opisu, lecz jako proces przekształcenia badanego przedmiotu w "obiekt”, czyli oddzielenie tekstowych przedstawień świata od samego świata w nich przedstawionego, które następowało za pomocą oderwania analizowanego obiektu od kontekstu

75 BPP476, s. 303.

76 A. Januszkiewicz Listy ze stepów kirgiskich, s. 154.

77 P. Rodak Rzeczy pisane, rzeczy napisane. O materialności praktyk piśmiennych, w: Literatura i „faktury" historii XX (iXXI) wieku, red. A. Molisak, J. Wierzejska, T. Wójcik, A. Zieniewicz, Elipsa, Warszawa 2014, s. 115. 
jego poznawania i umieszczenie go wewnątrz paradygmatów interpretacyjno-naukowych zniekształcających zawartość merytoryczną dziennika, bowiem jak podkreślał Walter Ong, ,druk sugeruje daleko silniej niż pismo, że słowa są rzeczami"78. Sam akt publikacji, nawet w przypadku tego samego tekstu, oznaczał nie tylko zmianę postaci materialnej czy medialnej, lecz także transformację grona czytelników oraz skalę zasięgu i oddziaływania tekstu, prowadząc do uzyskania autonomii na wzór „autonomii dzieła literackiego" dotyczącej przede wszystkim niezależności „znaczenia wypowiedzi"79. W konsekwencji całkowitego oderwania dziennika osobistego i listów od osoby je piszącej poprzez technologię druku, dokumenty osobiste Januszkiewicza mogły być odczytywane na nieskończenie wiele sposobów. Były one rozpatrywane np. przez pryzmat narodowej martyrologii i „cierpienia w niewoli u zaborcy" ${ }^{80}$ bądź poprzez "progresywne" $i$,rewolucyjne" spojrzenie indoktrynacyjnej historiografii radzieckiej ${ }^{81}$, bądź też z perspektywy teorii postkolonialnej ukazującej Januszkiewicza w niejednoznacznej roli „zdobywcy kolonialnego" ${ }^{2}$. Podobne praktyki odczytywania tekstów „biograficznych” polegały, po pierwsze, na skupieniu uwagi badaczy wyłącznie na tekstach drukowanych, po drugie, na odrywaniu przez nich dziennika czy korespondencji od kontekstu ich prowadzenia? Tym samym dokonywano operacji „obiektywizacji” przekazu, umożliwiającej traktowanie dokumentów osobistych Januszkiewicza jako niezależnego, skończonego materiału historycznego, a następnie ich odczytywanie poprzez wybrany pryzmat ideologiczny bądź paradygmat naukowy. Natomiast spojrzenie na dokumenty osobiste z perspektywy praktyki pisania i funkcji odgrywanej w życiu jednostki je piszącej pozwala inaczej spojrzeć na stronę semiotyczną, a także zaproponować

78 W.J. Ong Oralność i piśmienność, s. 183.

79 G. Godlewski Słowo - pismo - sztuka słowa. Perspektywy antropologiczne, Wydawnictwa UW, Warszawa 2008, s. 319.

80 M. Janik Dzieje Polaków na Syberii, Krakowska Spółka Wydawnicza, Kraków 1928; A. Kuczyński Polacy w Kazachstanie: Zesłania - Dziedzictwo - Nadzieje - Powroty, Kubajak, Krzeszowice 2014; A. Kuczyński Syberyjskie szlaki, Ossolineum, Wrocław 1972.

81 G. Sapargalijew, W. Djakow Polacy w Kazachstanie w XIX w., przeł. A. Trombala, J. Plater, Czytelnik, Warszawa 1982; W.A. Djakow Udział Polaków w badaniach i zagospodarowaniu Syberii, „Przegląd Historyczny" 1974 nr 65/4; W.A. Djakow Polscy zesłańcy w Syberii Zachodniej i północnym Kazachstanie (1830-1862), w: Polacy w Kazachstanie. Historia i współczesność, red. S. Ciesielski, A. Kuczyński, Wydawnictwo UWr, Wrocław 1996.

82 T. Ewertowski Zesłaniec kolonizatorem, "Listy ze stepów kirgizkich”'Adolfa Januszkiewicza, Postkolonializm/ postsekularyzm, "Interlinie” $2013 \mathrm{nr} 1$ (6). 
nowe perspektywy interpretacyjne. Dziennik Adolfa Januszkiewicza stanowi bowiem przykład stopniowego, świadomego kreowania własnego portretu jako pioniera, zgodnie z popularną w XIX wieku narracją eksploratorską. Praca ta została dokończona przez kolejnych redaktorów, będących do pewnego stopnia współautorami opublikowanego tekstu, który przybrał postać swoistego „pomnika” Januszkiewicza, pozostawionego dla następnych pokoleń.

\section{Abstract}

\section{Karina Gaibulina}

UNIVERSITY OF ST.GALLEN, SWITZERLAND

The (Auto)Biography of a Pioneer: Adolf Januszkiewicz's Diary and Letters

Gaibulina discusses how the Polish exile Adolf Januszkiewicz (1803-57) came to be represented as a pioneer and discoverer of the Central Asian terra incognita. His private correspondence and travel journal became an explorer's work of travel writing. To trace this development Gaibulina draws on the theory of writing practices and analyses subsequent stages of editorial work. She shows how the transition from one genre of writing to another (diary, epistolary writing, print) directly influences the content of the message. She also asks what role the text originally had in the writer's life, as well as its dialogical and intertextual relations.

\section{Keywords}

Central Asia, Adolf Januszkiewicz, writing practices, pioneer, diary writing, editorial work 